\title{
New insights in the genetics of isolated hypogonadotropic hypogonadism
}

\author{
André Iovane ${ }^{1}$, Chantal Aumas ${ }^{1}$ and Nicolas de Roux ${ }^{1,2}$ \\ ${ }^{2}$ Laboratoire d'Hormonologie et Biologie Moléculaire, Hôpital de Bicêtre, 75 rue du General Leclerc, 94270 Le Kremlin Bicetre, France and ${ }^{1}$ INSERM \\ U584, Faculté de Médecine Necker-Enfants Malades, 156 rue de Vaugirard, 75015 Paris, France \\ (Correspondence should be addressed to N de Roux, Laboratoire d'Hormonologie et Biologie Moléculaire, Hôpital de Bicêtre, 75 rue du General Leclerc, \\ 94270 Le Kremlin Bicetre, France; Email: deroux@necker.fr)
}

\begin{abstract}
Isolated gonadotropic deficiency or isolated hypogonadotropic hypogonadism is defined as a low sexual hormone secretion by the gonads associated with low LH and FSH plasma levels. Kallmann syndrome is defined as a congenital isolated gonadotropic deficiency associated with anosmia whereas the phenotype of the idiopathic form is limited to the gonadotropic axis. For several years, it has been known that mutations of the KAL-1 gene or loss-of-function mutations of GnRH receptor did not explain all familial cases of isolated gonadotropic deficiency with or without anosmia. Thus the existence of other genes playing a major role in the physiology of the gonadotropic axis was highly suggested. In 2003, fibroblast growth factor receptor 1 (FGFR1) and GPR 54 were shown to be two of these genes. FGFR1 loss-of-function mutations were reported in Kallmann syndrome whereas inactivating mutations of GPR 54 were described in the idiopathic form of the gonadotropic deficiency. These genetic studies have opened up a new chapter in the physiology and the pharmacology of the gonadotropic axis.
\end{abstract}

European Journal of Endocrinology 151 U83-U88

\section{Introduction}

The integrity of the gonadotropic axis leads to normal sexual differentiation during fetal life and puberty, and therefore normal fertility. Hypogonadotropic hypogonadism $(\mathrm{HH})$ or gonadotropic deficiency is defined by low gonadal sexual hormone plasma levels associated with normal or low follicle-stimulating hormone (FSH) and luteinizing hormone (LH) plasma levels. Congenital $\mathrm{HH}$ may be isolated or combined with other hormonal deficiencies. Association of gonadotropic deficiency with anosmia defines Kallmann syndrome whereas a normal sense of smell defines idiopathic $\mathrm{HH}(\mathrm{IHH})$ (1). In IHH patients, several defects have been described in genes which encode for proteins with biological function in the gonadotropic axis, such as the gonadotropin releasing hormone (GnRH) receptor and the beta sub-units of LH and FSH $(2,3)$ (Fig. 1). These genes were defined as natural candidates and these studies have described clinical repercussions of complete or partial congenital inhibition of the gonadotropic axis. In Kallmann syndrome, genome mapping has led to the characterization of defects in an unsuspected gene encoding for a protein with unknown function $(4,5)$. This protein is involved in the olfactory bulb development and neuron chimiotactism (6). In 2003, novel genetic defects were reported in fibroblast growth factor (FGF) receptor 1 (FGFR1) and GPR54, two different membrane receptors with previously described biological functions (7-9). Loss-of-function mutations of the FGFR1 were reported in Kallmann syndrome (8) whereas GPR54 inactivating mutations were described in the idiopathic form of hypogonadotropic hypogonadism $(7,9)$. These studies provide new insights into the developmental biology of the GnRH neurons or the hormonal regulation of the gonadotropic axis. This review is focused on FGFR1 and GPR 54 as the reader can find several general reviews on the other genes elsewhere $(3,4)$.

\section{Genetic heterogeneity of isolated hypogonadotropic hypogonadism}

Since 1997 several loss-of-function mutations of the GnRH receptor have been described. The phenotype is a continuum between a complete gonadotropic deficiency and a partial deficiency called fertile eunuch in man (2). Phenotype-genotype correlation studies indicate that the phenotype is related to the functional alteration of the GnRH receptor (2). A strong inhibition of the GnRH receptor results in a deep hypogonadism. However, variability of the phenotype has been observed in affected related subjects bearing identical mutations suggesting that environmental factors or modifier genes may influence the phenotype (10). All reports confirm the absence of specific clinical features related to mutations of the GnRH receptor in hypogonadotropic hypogonadism patients.

The majority of IHH cases are sporadic (1). Hypogonadism due to inactivating GnRH receptor (GnRHR) mutation is transmitted as a recessive trait. The frequency of GnRHR loss-of-function mutations is 50\% 


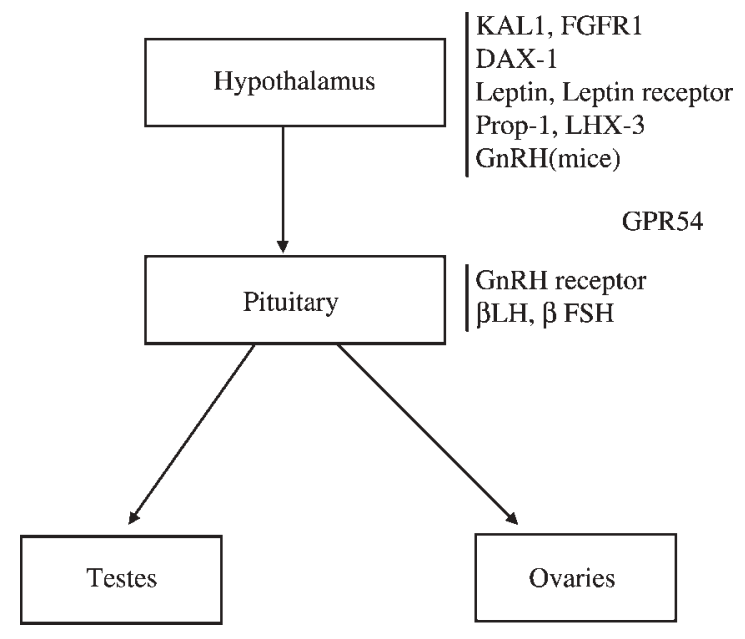

Figure 1 Genes involved in congenital hypogonadotropic hypogonadism.

in familial cases but this frequency drops below 10\% in total cases comprising sporadic and familial cases (11). This genetic heterogeneity was confirmed by linkage analysis in informative families $(7,12)$. Thus the presence of other genes encoding for unsuspected or undiscovered proteins playing a major role in the gonadotropic axis was suggested.

\section{The telomeric end of chromosome 19: a candidate region for IHH}

Discrimination of hypothalamic defects from pituitary defects remains difficult in puberty disease. Moreover, functional abnormality of hormones synthesized outside the brain, such as leptin, was also described in HH (13). Animal models are not very informative as several differences in the initiation process of puberty have been described between rodent and primate. Genome mapping is one alternative to characterize new genes in such rare diseases. Highly detailed genetic maps combined with human genome sequencing databases have opened up new perspectives in the reproduction field. Simulation work has shown that one informative family with consanguineous parents may be enough to characterize a new genetic defect transmitted as a Mendelian trait (14). Such an approach has been followed by two groups in idiopathic HH familial cases $(7,9)$.

De Roux et al. studied a consanguineous family with five affected siblings (7). The propositus was a 20-yearold man referred for hypogonadism with low LH and FSH plasma levels. A GnRH test showed a modest LH and FSH response. The bone age was fifteen years in the propositus. Other anterior pituitary hormones were normal. Three brothers had similar phenotypes and one sister was in primary amenorrhea with normal LH and FSH plasma levels (see Fig. 2). Puberty was normal in two sisters and one brother. The GnRH receptor gene was rejected by linkage analysis with anonymous markers from chromosome 4. A genome mapping performed with 300 anonymous genetic markers led to the localization of a new candidate region at the telomeric end of the short arm of chromosome 19. Fine mapping restricted this candidate region to a chromosome fragment of $2000 \mathrm{~kb}$. A similar localization was reported by Seminara et al. in another informative family from Saudi Arabia showing high consanguinity (9). The phenotype described was also limited to the gonadotropic axis with a normal sense of smell.

\section{GPR 54: an unsuspected candidate gene}

More than forty genes or open reading frames are described within this candidate region which has one of the highest gene densities in the human genome. Several genes were potentially candidates such as the NR3B gene which encodes for a subunit of the N-methyl-Daspartate (NMDA) receptor (15) which is involved in the puberty initiation process (16). EPLG3 is a protein playing a role in neuron migration (17). Both genes were rejected by sequencing the coding sequence (7). GPR 54 was another candidate gene. This receptor is a G-protein-coupled receptor first defined as an orphan receptor (18). It was cloned by PCR with degenerated primers defined within transmembrane segments which are highly conserved in the G-protein-coupled receptor family. The choice of GPR 54 as a candidate gene was mainly based on the gene expression pattern and one in vivo study. The GPR 54 gene is expressed within the hypothalamus and the pituitary $(19,20)$. The injection of KiSS-1 which was characterized as the ligand of GPR 54 resulted in an increase in the oxytocin plasma level in mouse (21). These results suggested a role for GPR 54 in neuroendocrinology.

In the family described by the French group, PCR amplification of the 5 exons of the GPR 54 gene from genomic DNA of the propositus clearly showed a shorter PCR product in the propositus when compared with unaffected patients (7). This reduced length is due to a deletion of 152 nucleotides encompassing the $3^{\prime}$ end of intron 4 and the $5^{\prime}$ extremity of exon 5 which removed the acceptor splice site of intron 4 . This deletion removed the $\mathrm{C}$-terminal end of the receptor from the middle of the intracellular loop 3 to the end. It is well known that such truncated G-protein-coupled receptors (GPCR) are inactive. The genetic defects described in this family resulted in inactivation of GPR 54.

At the same time, Seminara et al. showed that HH may be caused by inactivation of GPR 54 in an $\mathrm{HH}$ familial case previously shown to be linked to the short arm of chromosome 19 (9). In this family, the group characterized one homozygote L148S mutation of GPR54 in affected patients. Expression of the L148S-mutated GPR 54 receptor in COS-7 cells has shown that this mutation abolishes phospholipase $C$ stimulation by KiSS-1. By screening a cohort of 63 IHH and 20 Kallmann syndrome patients, they found 


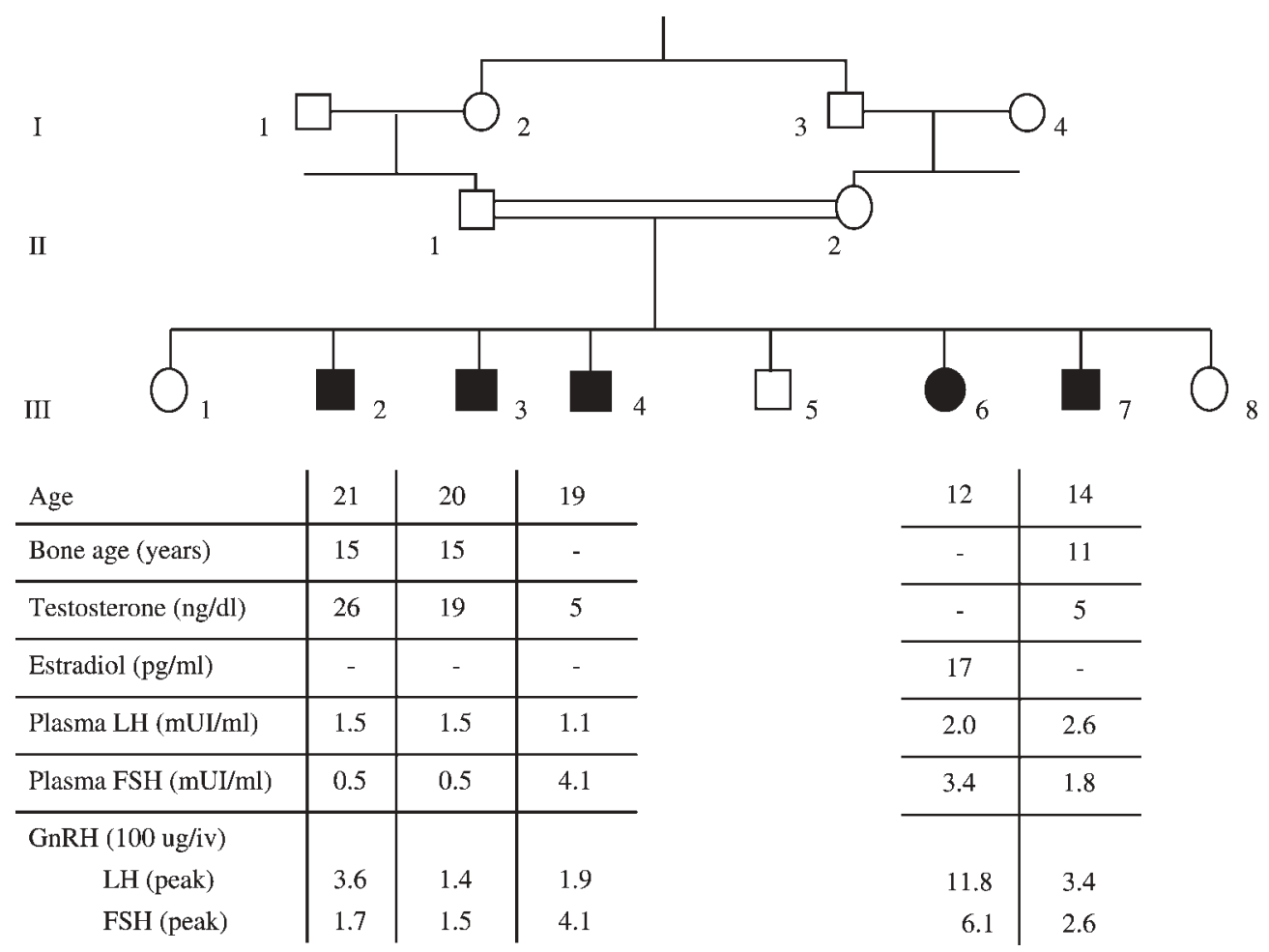

Figure 2 Pedigree of the hypogonadotropic hypogonadism due to GPR54 deletion (7).

two heterozygous mutations in one sporadic case. One mutation is a non-stop mutation at the stop codon 399. The second mutation substituted a stop codon at arginine 331. This patient was a compound heterozygote for these two mutations. Expression of both mutations in COS-7 cells confirmed that they both induce loss-of-function of GPR 54.

These two genetic studies performed in the USA and in France demonstrated that isolated hypogonadotropic hypogonadism may be due to an inactivation of GPR 54 in humans.

\section{GPR 54 invalidation in mice: a new model of isolated hypogonadotropic hypogonadism}

The physiological role of GPR 54 in the gonadotropic axis of mammals was definitively confirmed by its invalidation in mice. The phenotype observed in mice invalidated for GPR54 (GPR54 - / - ) was also limited to the gonadotropic axis (9). At birth, sexual differentiation seems to be normal (22). The phenotype observed at seven weeks of age showed that GPR $54-/-$ male mice have a reduced ano-genital length, small testes and micropenia. The GPR54 - / - female mice showed reduced volume of mammary glands, small ovaries and an infantile uterus. In both sexes, the sexual hormones, LH and FSH plasma levels are low. A GnRH test performed in GPR54 - / - mice at seven weeks showed a persistent but small increase in LH and FSH plasma levels (9).
These results suggest a normal expression of the GnRH receptor at the gonadotrope cell surface of the GPR $54-1-$. The GnRH concentrations are similar in the hypothalamus extracts of GPR $54-/-$ mice when compared with wild-type mice. A normal phenotype was observed in the heterozygous GPR $54+1-$ mice. These genetic studies performed in two different genetic backgrounds have clearly confirmed the involvement of GPR 54 in the regulation of the gonadotropic axis in mice. It suggested that GPR 54 may act at the hypothalamic level but a role at the pituitary level cannot be ruled out.

We sequenced 250 DNA samples from IHH sporadic cases and familial cases. Three homozygous mutations were found in three familial cases and none in sporadic cases (M Comenge, A Iovane, C Aumas, M El-Kholi and $\mathrm{N}$ de Roux, unpublished results).

\section{GPR54: a G-protein-coupled receptor with diverse functions}

GPR54 is a 398 amino acids G-protein-coupled receptor with a short extracellular domain, seven transmembrane domains linked by extracellular and intracellular loops and an intracellular domain (18). Potential $\mathrm{N}$-glycosylation sites are present within the extracellular domain as well as phosphorylation sites within the intracellular domain. It shows $40 \%$ homology with the galanin receptors. It is mainly coupled to phospholipase $\mathrm{C}$ beta but it may also activate other transduction 
pathways such as phospholipase A2 (21). MAP kinases were shown to be activated by GPR 54 in CHO cells (21). These transduction pathways are implicated in $\mathrm{GnRH}$ regulation of $\mathrm{LH}$ and $\mathrm{FSH}$ synthesis and secretion (23).

GPR 54 cDNA has been cloned in human, rat and mouse, and in dano-rerio and amphioxus. GPR 54 is thus expressed in invertebrates as well as vertebrates. However, the link between the gonadotropic axis and GPR54 in amphioxus is hypothetical as the existence of this hormonal axis is not confirmed in this invertebrate. GPR 54 is expressed throughout the central nervous system (20), the hypothalamus, the pituitary, the pancreas, and the prostate but the highest expression was observed in the placenta $(19-21)$. However, cells expressing GPR 54 in brain need to be defined precisely.

The ligand of GPR 54 is a 54 residue peptide (kisspeptide54) derived from KiSS-1 protein by a complex post-translational process (24). KiSS-1 protein was characterized by substractive cloning and differential display in the C8161 melanoma cell line in which the cells have lost their metastatic potential after transfer of an intact copy of human chromosome 6 (25). KiSS-1 expression was up-regulated in this metastasisdeficient chromosome 6/melanoma hybrid cell line. The KiSS-1 gene is localized on chromosome 1 (1q32). It was proposed that the KiSS-1 gene is transregulated by transcription factors encoded by genes localized within the human chromosome 6 (26).

The predicted KiSS-1 protein consists of a 145 amino acid protein (25) (Fig. 3). Protein amino acid sequence analysis has suggested several post-translational modifications as peptide signal sequences and three dibasic motifs representing potential cleavage sites by proconvertases. Mass spectrometry analysis of the GPR 54 human ligand showed that it is a 54 amino acid peptide derived from the KiSS-1 protein (19-21). It was confirmed that kisspeptide 54 results from proteolytic cleavages at dibasic sites $(19,21)$. The C-terminal end of Kisspeptide 54 is amidated on phenylalanine or tyrosine residues at RF or RY motifs. Several RF-amide peptides have already been described in insects but very few have been described in mammals.

Kisspeptide 54 was first characterized by purification from placenta extracts $(19,21)$ and then from plasma of pregnant women (27). Shorter forms of 14 or 13

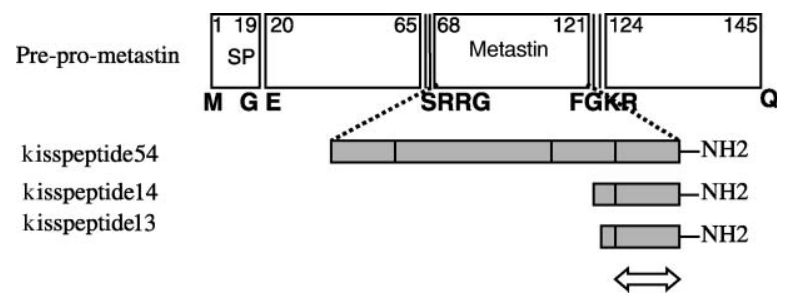

Figure 3 Placenta molecular forms of the GPR54 ligand. Molecular forms derived from proteolytic maturation of KiSS-1 protein are indicated. Double arrow indicates the shorter peptide leading to GPR54 activation. SP, signal peptide. residues were also described but they were considered as degradation products although both have a C-terminal RF-amidated motif (21). The shortest form of the ligand leading to GPR 54 activation is 10 residues in length. These shorter peptides have a higher affinity for GPR54 than Kisspeptide54 (21).

Two specific antibodies have shown that kisspeptide 54 is present in plasma at very low concentrations $(\mathrm{fmol} / \mathrm{ml})$ in both sexes (27). The origin of this plasma kisspeptide 54 remains unknown.

GPR 54 invalidation in mice and natural loss-of-function mutations in humans have shown the role of GPR 54 in the regulation of the gonadotropic axis. In the brain, GPR 54 may act as a neuromodulator of the gonadotropic axis. This function may be considered as the main biological function of GPR 54 in mammals. kisspeptides and GPR 54 may act as physiological regulators of the cellular adherence or invasion. In placenta, GPR 54 and kisspeptide10 are inhibitors of the trophoblast invasion by a paracrine or endocrine mechanism (28). In vivo and in vitro experiments have shown that kisspeptides and GPR 54 regulate the metastasis potential of melanoma and breast cancer cell lines (24). This metastasis suppressor function was also suggested by clinical studies showing a correlation between a decrease in KiSS-1 gene expression in tumor cells and metastasis outcome in several cancers (29-31). This function in cellular adherence or invasion may be considered minor in normal tissue as normal development occurred in GPR 54 - / - invalidated mice. However, in tumor cells, KiSS-1 or GPR54 may be one of the last factor which preserve tumor cells from metastasis.

\section{Loss-of-function mutations of FGFR 1 in Kallmann syndrome}

Several mutations and deletions of the KAL1 gene have been described in the X-linked form of Kallmann syndrome $(4,5)$. Autosomal-dominant as well as -recessive transmission have also been described (32). Autosomaldominant transmission was proposed in families with incomplete penetrance for the gonadotropic deficiency. In several families, it was reported that relatives of the propositus with classic Kallmann syndrome may have isolated anosmia. Segregation analysis suggested that autosomal Kallmann syndrome is caused by at least two different autosomal gene defects.

Dode et al. studied two sporadic cases showing different contiguous gene syndromes that both included Kallmann syndrome (8). They characterized two interstitial deletions within the short arm of chromosome 8 . Fine mapping of the deletion led this group to define a new candidate region of $540 \mathrm{~Kb}$ for the autosomal Kallmann syndrome. The FGF receptor 1 gene was present in this candidate region; it was considered a candidate gene as FGF receptors are involved in olfactory bulb development (33). Several heterozygous nonsense or missense mutations of FGFR1 were characterized in 
familial cases and sporadic cases (8). Small deletions leading to frameshift of the coding sequence and synthesis of truncated FGFR1 were also reported. Several mutations substituted residues involved in the receptor folding or in signal transduction $(8,34)$. This study led to the conclusion that autosomal Kallmann syndrome may be due to inactivation of the FGF receptor 1 . The frequency is low and explains around $10 \%$ of the total cases of Kallmann syndrome $(8,34)$. A constitutive mutation of the FGFR1 has been described in Pfeiffer syndrome which is a recurrent mutation that constitutively activates the FGF receptor 1 (35). No abnormality of the gonadotropic axis was described in this syndrome.

The hypogonadism observed in KAL1 mutation is similar to the gonadotropic deficiency described in FGFR1 mutations. However, dental agenesis and cleft palate seem to be specific to FGFR1 loss-of-function mutations (34). Unilateral renal agenesia was only reported in KAL1 mutation. Bimanual synkinesia is not specific to the X-linked Kallmann syndrome (8).

The phenotype expressivity of congenital isolated $\mathrm{HH}$ is very variable. The phenotype may be limited to anosmia in subjects bearing FGFR1 loss-of-function or KAL1 mutations. Such variability may depend directly on olfactory bulb development (36). However, variable gonadotrope deficiency was also reported in $\mathrm{IHH}$ cases due to loss-of-function $\mathrm{GnRH}$ receptor mutations $(10,37)$. Further work is needed to determine whether similar environmental or modifier genes determine phenotype expressivity in Kallmann syndrome and congenital idiopathic hypogonadotropic hypogonadism.

\section{Molecular genetics of the isolated hypogonadotropic hypogonadism: a panel of four genes}

In Kallmann syndrome, hypogonadism is due to a $\mathrm{GnRH}$ neuron migration defect related to the absence of olfactory bulb development. The anosmia is thus constant, although it may be partial in some cases (38). FGFR1 and KAL1 which are involved in olfactory bulb development should be analyzed in Kallmann syndrome. KAL1 gene analysis must be limited to male cases. FGFR1 gene should be genotyped in female or male cases. A dominant transmission of isolated anosmia as well as dental agenesis or cleft palate in the propositus will orient the analysis towards the FGFR 1 gene.

In idiopathic HH due to GnRH receptor or GPR 54 inactivating mutations, the fetal development of the GnRH neuron is normal and the hypogonadism is related to a defect in GnRH secretion or the pituitary response to GnRH stimulation. The phenotypes linked to GnRH or GPR 54 loss-of-function mutations are similar and both gene defects are transmitted as recessive traits; these two genes should be analyzed in idiopathic $\mathrm{HH}$.

\section{Conclusion}

Human genetics has opened up a new chapter in the physiology of the gonadotropic axis. Loss-of-function of GPR 54 results in idiopathic hypogonadotropic hypogonadism. FGFR1 inactivation is described in autosomal Kallmann syndrome. GPR 54 invalidation in mice indicates that GPR 54 may regulate GnRH secretion by the hypothalamus or the pituitary response to GnRH stimulation. FGFR1 is involved in the development of the olfactory bulb. The high variability of the phenotype linked to loss-of-function mutations of FGFR1 suggests that modifier genes or environmental factors are involved in determining the phenotype. GPR 54 is a G-protein-coupled receptor involved in the dynamic regulation of the gonadotropic axis. It may thus become a new pharmacological target to modulate FSH and LH secretion.

\section{References}

1 Seminara SB, Hayes FJ \& Crowley WF Jr. Gonadotropin-releasing hormone deficiency in the human (idiopathic hypogonadotropic hypogonadism and Kallmann's syndrome): pathophysiological and genetic considerations. Endocrine Reviews $199819521-539$.

2 Karges B, Karges W \& de Roux N. Clinical and molecular genetics of the human GnRH receptor. Human Reproduction Update 20039 523-530.

3 Themmen APN \& Huhtaniemi IT. Mutations of gonadotropins and gonadotropin receptors: elucidating the physiology and pathophysiology of pituitary-gonadal function. Endocrine Reviews $200021551-583$.

4 Achermann JC, Ozisik G, Meeks JJ \& Jameson JL. Genetic causes of human reproductive disease. Journal of Clinical Endocrinology and Metabolism 200287 2447-2454

5 Quinton R, Duke VM, Robertson A, Kirk JM, Matfin G, de Zoysa PA, Azcona C, MacColl GS, Jacobs HS, Conway GS, Besser M, Stanhope RG \& Bouloux PM. Idiopathic gonadotrophin deficiency: genetic questions addressed through phenotypic characterization. Clinical Endocrinology 200155 163-174.

6 Soussi-Yanicostas N, de Castro F, Julliard AK, Perfettini I, Chedotal A \& Petit C. Anosmin-1, defective in the X-linked form of Kallmann syndrome, promotes axonal branch formation from olfactory bulb output neurons. Cell 2002109 217-228.

7 de Roux N, Genin E, Carel JC, Matsuda F, Chaussain JL \& Milgrom E. Hypogonadotropic hypogonadism due to loss of function of the KiSS1-derived peptide receptor GPR54. PNAS 2003 $10010972-10976$

8 Dode C, Levilliers J, Dupont JM, De Paepe A, Le Du N, Soussi-Yanicostas N, Coimbra RS, Delmaghani S, CompainNouaille S, Baverel F, Pecheux C, Le Tessier D, Cruaud C, Delpech M, Speleman F, Vermeulen S, Amalfitano A, Bachelot Y, Bouchard P, Cabrol S, Carel JC, Delemarre-van de Waal H, Goulet-Salmon B, Kottler ML, Richard O, Sanchez-Franco F, Saura R, Young J, Petit C \& Hardelin JP. Loss-of-function mutations in FGFR1 cause autosomal dominant Kallmann syndrome. Nature Genetics 200333 $463-465$.

9 Seminara SB, Messager S, Chatzidaki EE, Thresher RR, Acierno JS Jr, Shagoury JK, Bo-Abbas Y, Kuohung W, Schwinof KM, Hendrick AG, Zahn D, Dixon J, Kaiser UB, Slaugenhaupt SA, Gusella JF, O'Rahilly S, Carlton MB, Crowley WF Jr, Aparicio SA \& Colledge WH. The GPR 54 gene as a regulator of puberty. New England Journal of Medicine 2003349 1614-1627.

10 de Roux N, Young J, Brailly-Tabard S, Misrahi M, Milgrom E \& Schaison G. The same molecular defects of the gonadotropinreleasing hormone receptor determine a variable degree of 
hypogonadism in affected kindred. Journal of Clinical Endocrinology and Metabolism $1999 \mathbf{8 4} 567-572$.

11 Beranova M, Oliveira LM, Bedecarrats GY, Schipani E, Vallejo M, Ammini AC, Ouintos JB. Hall JE, Martin KA, Hayes FJ, Pitteloud N, Kaiser UB, Crowley WF Jr \& Seminara SB. Prevalence, phenotypic spectrum, and modes of inheritance of gonadotropin-releasing hormone receptor mutations in idiopathic hypogonadotropic hypogonadism. Journal of Clinical Endocrinology and Metabolism $2001861580-1588$.

12 Bo-Abbas Y, Acierno JS Jr, Shagoury JK, Crowley WF Jr \& Seminara SB. Autosomal recessive idiopathic hypogonadotropic hypogonadism: genetic analysis excludes mutations in the gonadotropin-releasing hormone $(\mathrm{GnRH})$ and GnRH receptor genes. Journal of Clinical Endocrinology and Metabolism $2003 \mathbf{8 8} 2730-2737$.

13 Pralong FP \& Gaillard RC. Neuroendocrine effects of leptin. Pituitary $2001425-32$.

14 Genin E, Todorov AA \& Clerget-Darpoux F. Optimization of genome search strategies for homozygosity mapping: influence of marker spacing on power and threshold criteria for identification of candidate regions. Annals of Human Genetics 199862 419-429.

15 Chatterton JE, Awobuluyi M, Premkumar LS, Takahashi H, Talantova M, Shin Y, Cui J, Tu S, Sevarino KA, Nakanishi N, Tong G, Lipton SA \& Zhang D. Excitatory glycine receptors containing the NR3 family of NMDA receptor subunits. Nature $2002 \mathbf{4 1 5} 793-798$.

16 Terasawa E \& Fernandez DL. Neurobiological mechanisms of the onset of puberty in primates. Endocrine Reviews 2001 22 111-151.

17 Carpenter MK, Shilling H, VandenBos T, Beckmann MP, Cerretti DP, Kott JN, Westrum LE, Davison BL \& Fletcher FA. Ligands for EPH-related tyrosine kinase receptors are developmentally regulated in the CNS. Journal of Neuroscience Research $199542199-206$.

18 Lee DK, Nguyen T, O’Neill GP, Cheng R, Liu Y, Howard AD, Coulombe N, Tan CP, Tang-Nguyen AT, George SR \& O'Dowd BF. Discovery of a receptor related to the galanin receptors. FEBS Letters $1999 \mathbf{4 4 6} 103-107$.

19 Ohtaki T, Shintani Y, Honda S, Matsumoto H, Hori A, Kanehashi K, Terao Y, Kumano S, Takatsu Y, Masuda Y, Ishibashi Y, Watanabe T, Asada M, Yamada T, Suenaga M, Kitada C, Usuki S, Kurokawa T, Onda H, Nishimura O \& Fujino M. Metastasis suppressor gene KiSS-1 encodes peptide ligand of a G-protein-coupled receptor. Nature 2001 411 613-617.

20 Muir AI, Chamberlain L, Elshourbagy NA, Michalovich D, Moore DJ, Calamari A, Szekeres PG, Sarau HM, Chambers JK, Murdock P, Steplewski K, Shabon U, Miller JE, Middleton SE, Darker JG, Larminie CG, Wilson S, Bergsma DJ, Emson P, Faull R, Philpott KL \& Harrison DC. AXOR 12, a novel human G-protein-coupled receptor, activated by the peptide KiSS-1. Journal of Biological Chemistry 2001276 28969-28975.

21 Kotani M, Detheux M, Vandenbogaerde A, Communi D, Vanderwinden JM, Le Poul E, Brezillon S, Tyldesley R, SuarezHuerta N, Vandeput F, Blanpain C, Schiffmann SN, Vassart G \& Parmentier M. The metastasis suppressor gene KiSS-1 encodes kisspeptins, the natural ligands of the orphan G-protein-coupled receptor GPR54. Journal of Biological Chemistry 2001276 34631-34636.

22 Funes S, Hedrick JA, Vassileva G, Markowitz L, Abbondanzo S, Golovko A, Yang S, Monsma FJ \& Gustafson EL. The KiSS-1 receptor GPR 54 is essential for the development of the murine reproductive system. Biochemical and Biophysical Research Communications $20033121357-1363$.

23 Kraus S, Naor Z \& Seger R. Intracellular signaling pathways mediated by the gonadotropin-releasing hormone (GnRH) receptor. Archives of Medical Research 200132 499-509.

24 Harms JF, Welch DR \& Miele ME. KiSS-1 metastasis suppression and emergent pathways. Clinical and Experimental Metastasis $20032011-18$.

25 Lee JH, Miele ME, Hicks DJ, Phillips KK, Trent JM, Weissman BE \& Welch DR. KiSS-1, a novel human malignant melanoma metastasis-suppressor gene. Journal of the National Cancer Institute 199688 1731-1737.

26 Goldberg SF, Miele ME, Hatta N, Takata M, Paquette-Straub C, Freedman LP \& Welch DR. Melanoma metastasis suppression by chromosome 6: evidence for a pathway regulated by CRSP3 and TXNIP. Cancer Research 200363 432-440.

27 Horikoshi Y, Matsumoto H, Takatsu Y, Ohtaki T, Kitada C, Usuki S \& Fujino M. Dramatic elevation of plasma metastin concentrations in human pregnancy: metastin as a novel placentaderived hormone in humans. Journal of Clinical Endocrinology and Metabolism $2003 \mathbf{8 8} 914-919$.

28 Bilban M, Ghaffari-Tabrizi N, Hintermann E, Bauer S, Molzer S, Zoratti C, Malli R, Sharabi A, Hiden U, Graier W, Knofler M, Andreae F, Wagner O, Quaranta V \& Desoye G. Kisspeptin-10, a KiSS-1/metastin-derived decapeptide, is a physiological invasion inhibitor of primary human trophoblasts. Journal of Cell Science $20041171319-1328$.

29 Sanchez-Carbayo M, Belbin TJ, Scotlandi K, Prystowsky M, Baldini N, Childs G \& Cordon-Cardo C. Expression profiling of osteosarcoma cells transfected with MDR1 and NEO genes: regulation of cell adhesion, apoptosis, and tumor suppression-related genes. Laboratory Investigation 200383 507-517.

30 Shirasaki F, Takata M, Hatta N \& Takehara K. Loss of expression of the metastasis suppressor gene KiSS1 during melanoma progression and its association with LOH of chromosome 6q16.3q23. Cancer Research $2001617422-7425$.

31 Ikeguchi M, Yamaguchi K \& Kaibara N. Clinical significance of the loss of KiSS-1 and orphan G-protein-coupled receptor (hOT7T175) gene expression in esophageal squamous cell carcinoma. Clinical Cancer Research 200410 1379-1383.

32 Oliveira LM, Seminara SB, Beranova M, Hayes FJ, Valkenburgh SB, Schipani E, Costa EM, Latronico AC, Crowley WF Jr \& Vallejo M. The importance of autosomal genes in Kallmann syndrome: genotype-phenotype correlations and neuroendocrine characteristics. Journal of Clinical Endocrinology and Metabolism $2001861532-1538$.

33 Yazaki N, Hosoi Y, Kawabata K, Miyake A, Minami M, Satoh M, Ohta M, Kawasaki T \& Itoh N. Differential expression patterns of mRNAs for members of the fibroblast growth factor receptor family, FGFR-1-FGFR-4, in rat brain. Journal of Neuroscience Research 199437 445-452.

34 Sato N, Katsumata N, Kagami M, Hasegawa T, Hori N, Kawakita S, Minowada S, Shimotsuka A, Shishiba Y, Yokozawa M, Yasuda T, Nagasaki K, Hasegawa D, Hasegawa Y, Tachibana K, Naiki Y, Horikawa R, Tanaka T \& Ogata T. Clinical assessment and mutation analysis of Kallmann syndrome 1 (KAL1) and fibroblast growth factor receptor 1 (FGFR1, or KAL2) in five families and 18 sporadic patients. Journal of Clinical Endocrinology and Metabolism 200489 1079-1088.

35 Rutland P, Pulleyn LJ, Reardon W, Baraitser M, Hayward R, Jones B, Malcolm S, Winter RM, Oldridge M, Slaney SF, Poole MD \& Wilkie AOM. Identical mutations in the FGFR2 gene cause both Pfeiffer and Crouzon syndrome phenotypes. Nature Genetics 19959 173-176.

36 Hebert JM, Lin M, Partanen J, Rossant J \& McConnell SK. FGF signaling through FGFR 1 is required for olfactory bulb morphogenesis. Development $20031301101-1111$.

37 Wolczynski S, Laudanski P, Jarzabek K, Mittre H, Lagarde JP \& Kottler ML. A case of complete hypogonadotropic hypogonadism with a mutation in the gonadotropin-releasing hormone receptor gene. Fertility and Sterility $2003 \mathbf{7 9} 442-444$

38 Massin N, Pecheux C, Eloit C, Bensimon JL, Galey J, Kuttenn F, Hardelin JP, Dode C \& Touraine P. X chromosome-linked Kallmann syndrome: clinical heterogeneity in three siblings carrying an intragenic deletion of the KAL-1 gene. Journal of Clinical Endocrinology and Metabolism 200388 2003-2008.

Received 8 June 2004

Accepted 5 August 2004 